\title{
The Sonderkommando photographs: a possibility for reconciled commemoration of a sublime historical event ${ }^{\star}$
}

\author{
Paula Ramos Mollá \\ Universiteit van Amsterdam, Nederland, Amsterdam \\ E-mail: paurammo@gmail.com
}

Recibido: 26 de febrero de 2021 | Aceptado: 22 de abril de 2021

https://doi.org/10.17533/udea.ef.345415

\begin{abstract}
In this paper I consider the four images from Auschwitz analyzed by DidiHuberman in Images in Spite of All -the so-called Sonderkommando photographs- through the lens of the "historical sublime" as proposed by historian Eelco Runia. These photographs are taken as an example of a possible reconciled aesthetic experience with an "unimaginable" past that horrifies us. Moreover, I argue that aesthetic depictions are able to champion a model of historical commemoration which makes these events imaginable again. In order to show this, I will first employ the concept of the "sublime historical event" which Runia proposes to interpret the Holocaust's historical catastrophe. Runia's "historical sublime" provides a framework to understand the process of becoming what "we are no longer" through the invention of new identities that defy our former ones and explain historical discontinuities. Secondly, I will examine the Sonderkommando photographs by applying Runia's notion of commemoration to the viewer's aesthetic experience of these images. I will finally suggest the possibility of a reconciliation with our former identities, those who committed sublime historical acts with which we no longer identify, thanks to this aestheticized experience of commemoration.
\end{abstract}

Key words: historical sublime, Eelco Runia, Didi-Huberman, aesthetic experience, identity, historical reconciliation

* Este texto se encuentra vinculado a la investigación de Paula Ramos Mollá en torno a la imagen y sus efectos sobre la percepción colectiva realizada en la UvA. Concretamente, trata de vincular la experiencia estética con la responsabilidad histórica colectiva.

\section{Cómo citar este artículo}

Ramos Mollá, P. (2022). The Sonderkommando photographs: a possibility for reconciled commemoration of a sublime historical event. Estudios de Filosofía, 65, 193-204. https://doi. org/10.17533/udea.ef.345415

\section{OPEN \& ACCESS}




\title{
Las fotografías del Sonderkommando: una posibilidad de reconciliación al conmemorar un evento histórico sublime
}

\begin{abstract}
Resumen: En este artículo considero las cuatro imágenes de Auschwitz analizadas por Didi-Huberman en Imágenes pese a todo -las Ilamadas fotografías del Sonderkommandoa través del concepto de lo "histórico sublime" propuesto por el historiador Eelco Runia. Es más, sugiero que dichas fotografías son un ejemplo para una experiencia estética de reconciliación con un pasado "inimaginable" que nos horroriza. Para ello, primero utilizo el concepto de "evento histórico sublime", tal y como Runia lo expone, para interpretar la catástrofe histórica del Holocausto bajo estos términos. Lo "histórico sublime" nos provee de un marco teórico suficiente en este caso para comprender el proceso de devenir en algo que "no somos ya" a través de la invención de nuevas identidades que desafían aquellas que una vez fuimos y que explica el avance discontinuo de la historia. En segundo lugar, examino las fotos Sonderkommando aplicando la noción de conmemoración de Runia a la experiencia estética de estas imágenes. Por último, planteo la posibilidad de reconciliarnos con nuestras identidades pasadas, aquellas que cometieron actos históricos sublimes con los cuales ya no nos identificamos, gracias a esta experiencia estética de conmemoración.
\end{abstract}

Palabras clave: histórico sublime, conmemoración, Didi-Huberman, identidad, experiencia estética, reconciliación histórica

Paula Ramos Mollá is a researcher, writer and curator based in Amsterdam. Having graduated with a Bachelor's Degree in Humanities and Journalism from the Carlos III University and a Minor in Political Sciences, she has recently finished the ReMA in Philosophy at the University of Amsterdam. Paula's main research field is aesthetics, specifically visual studies. Her current research is focused on an interdisciplinary analysis of the digital image and its impact in our contemporary experiences of the artwork. Paula has previous research experience, having collaborated with research institutes such as ICON in Utrecht or DELab in Warsaw.

ORCID: 0000-0003-0905-9394 
The four photographs snatched by the Sonderkommando of crematorium $\mathrm{V}$ in Auschwitz address the unimaginable, and refute it, in the most harrowing way. In order to refute the unimaginable, several men took the collective risk of dying and, worse, of undergoing the punishment reserved for this kind of attempt: torture.

G. Didi-Huberman, Images in Spite of All, p. 19

\section{The Sonderkommando photographs}

How can something that has already happened turn into something purely unimaginable once it has become a thing of the past? The Sonderkommando photographs are four images taken by an unidentified Greek man called Alex -with no certain known surname-in 1944 inside Auschwitz's concentration camps. These images from the past are unique for two reasons: first of all, they were taken by the victims of their own massacre, those Jewish people belonging to the Sonderkommando who were forced to work along with the Nazis in the crematoriums; second of all, they weren't conceived as a form of a posteriori politicized art $^{1}$ but were the result of the victims wanting to be seen, to make visible what was unthinkable.

The first feature is what distinguishes these photographs, for instance, from the ones depicting the horrors of Abu Ghraib, where the U.S soldiers indiscriminately abused the inmates of the Iraqi prison. The second reason is what makes these images different from, for example, those elaborated by Alfredo Jaar in his series The Eyes of Gutete Emerita or Real Pictures, analyzed by Rancière (2009). Moreover, these four photographs are indeed a pristine example of the unveiling of what Rancière calls the "politics of aesthetics":

There is thus an 'aesthetics' at the core of politics that has nothing to do with Benjamin's discussion of the 'aestheticization of politics' specific to the 'age of the masses.' This aesthetics should not be understood as the perverse commandeering of politics by a will to art, by a consideration of the people qua work of art. If the reader is fond of analogy, aesthetics can be understood in a Kantian sense -re-examined perhaps by Foucault- as the system of a priori forms determining what presents itself to sense experience. It is a delimitation of [14] spaces and times, of the visible and the invisible, of speech and noise, that simultaneously determines the place and the stakes of politics as a form of experience (2004, p. 13).

1 The images from Auschwitz are not part of a politicized aesthetic regime in the sense Walter Benjamin described it in the socalled Artwork Essay as the "politicization of aesthetics" (Robertson, 2010, p. 42), however they are included in what was later described by Rancière as "primary aesthetics": "It is on the basis of [...] primary aesthetics that it is possible to raise the question of 'aesthetic practices' as I understand them, that is forms of visibility that disclose artistic practices, the place they occupy, what they 'do' or 'make' from the standpoint of what is common to the community" (Rancière, 2004, p. 13). 
The Sonderkommando photographs are innately political, for they constitute a living proof of a space in the realm of the visible that tried to be eradicated from within an aesthetic regime. After all, these pictures show the evidence of the Nazis' abuses, which they desperately tried to eradicate from the collective imaginary. As Didi-Huberman (2008) suggests, the policy of this aesthetic regime, was to suppress all proof of the Auschwitz catastrophic event: "archives - the memory of the obliteration- had to be obliterated" and hence, they kept "the obliteration forever in its unimaginable condition" (p. 22). The four images of the Sonderkommando show a new "distribution of the sensible" (Rancière, 2004, p. 12) within the current aesthetic regime: first of all, they make visible the past catastrophe they depict; second of all, they make it thinkable in our present aesthetic experience of the pictures and, third of all, imaginable for our own future. These images present a challenge to the distribution of the sensible because they defy the aesthetic core of the politics which surrounds them. In other words, because they "revolve[s] around what is seen and what can be said about it, around who has the ability to see and the talent to speak, around the properties of spaces and the possibilities of time" (Rancière, 2004, p. 13). Furthermore, because they show what had not yet been seen.

In Images $n^{\circ} 280$ and $n^{\circ} 281$ the viewer sees a pile of corpses being cremated from inside a gas chamber, where the photographer is located and which works as a frame in the picture. Image n⿳2 282 shows a group of naked women being taken to another gas chamber. The last image, $n^{0} 283$, just depicts some trees, capturing the nervousness of the photographer who has failed in snapping the moment (See the four images in page 204). These are all blurry, trembling images, which show in the form of a metonymy all the horrors suffered in the concentration camps, as I will discuss later. The Sonderkommando photographs are of great worth because they force a new distribution of the sensible by means of making visible a catastrophe which was considered to be impossible or, even more, to have not existed. They force upon the present a discussion about how this could have happened and who was responsible for allowing such horror.

\section{Four images of a sublime historical event}

The images from Auschwitz expose a redistribution of the sensible made visible through the aesthetics of politics which refutes the idea of "an unsayable Auschwitz" (DidiHuberman, 2008, p. 25) -thus, it gives the capacity of logos to the victims which is where, according to Rancière (1999), politics is played out. As Didi-Huberman (2008) recalls, these photographs do not just depict a historical event but are also an event in themselves, with their own phenomenology. Furthermore, Didi-Huberman highlights that this visual event has its own historical use and its own fragmentary truth:

A simple image: inadequate but necessary, inexact but true. True of a paradoxical truth, of course. I would say the image is the eye of history: its tenacious function 
of making visibleBut also it is in the eye of history: in a very local zone, in a moment of visual suspense, as the "eye" of a hurricane (2008, p. 39).

What kind of historical event do these visual fragments depict? I believe that these images actually act as the punctum of a sublime historical event, as described further ahead. A punctum is the presence that awakes in a photograph, a moment which, in Barthes words, "rises from the scene, shoots out of it like an arrow, and pierces me" (Barthes, 1982, p. 26). I will come back to the notion of presence proposed by Eelco Runia (2014) later and explain it in depth. However, to understand the phenomenological availability of the sublime historical event in the Sonderkommando photographs, we must be aware of how images have the ability to remember events and bring their past forward by means of "presence" which "is 'being in touch' -either literally or figuratively - with people, things, events, and feelings that made you into the person you are" (p. 140).

The four photographs from Auschwitz bring forward the presence of the Holocaust, in this case understood as a sublime historical event. Runia (2014) defines sublime historical events as those discontinuous moments in history which challenge our identity and the notion of a linear progression in history -they are, precisely, in his definition, these "unimaginable events" (p. 36). Furthermore, they are those unfathomable events that when we look at them, lead us to wonder "who are we that this could have happened?" (p. 37) Who are we that genocide in such a radical form as the Shoah -to take just one example- could happen despite being aesthetically and historically unimaginable? These images, as proof of the aesthetic unimaginable (Didi-Huberman, 2008) internal to the aesthetics of politics, make it impossible to "deny that we did what we did", so the question is now: "was it really us who did what was done?" (Runia, 2014, p. 38)

Eelco Runia (2014) elaborates in Moved by the Past ten thesis about our desire to commemorate, which only make sense when we acknowledge history as a discontinuous process constituted by "acts of people" (p. 36). Moreover, because history is acting, being surprised by one's deeds, historical events can only be but the result of this very same agency. However, historical acts are not the result of a rational narrative with legitimate motives and reasons, just as much history is not a grand narrative of progress in which we all identify with one singular historical experience. In Runia's words:

Committing history is a form of externalization: by committing sublime historical deeds, by doing things that are at odds with our identity, we place history outside ourselves. Committing history thus is a kind of burial: we take leave of ourselves as we have come to know ourselves and become what we as yet do not know. In the process we come to see what is lost forever: what we are no longer. This is my tenth and final thesis (2014, p. 57). 
Along his book, Runia (2014) seems to comply with Daryl Bem's "Self-perception theory" (p. 40). Nevertheless, I believe that this deidentification narrative suggested by Bem is the one which turns events like Auschwitz into something "unimaginable". If we were to follow Bem's explanation, we would be psychologically capable of disidentifying with these hideous historical acts by self-portraying ourselves as people not able of committing those crimes. This is a crucial discussion point for my understanding of the historical sublime as a concept which is actually able of bringing forward a reconciled commemoration of a past, condemned in the present.

In order to be truly reconciled with who we were and to move towards a new identity, our historical narrative cannot be one of mere dissociation with who we were. Neither can it solely reconstruct our past based on who we believe ourselves to be now. This narrative has to acknowledge a discontinuity in history and, moreover, understand how we, as historical agents, commit deeds which horrify us -thus, sublime historical events exemplified in this case by the Holocaust sublime (Jay, 2018; Sanbonmatsu, 2009). ${ }^{2}$ In this sense, the notion of the historical sublime helps us realize the discontinuity and incomprehensibility of certain historical acts, while keeping history intelligible. Only after taking this step towards responsibility instead of deidentification, we might conceive of historical events as a possibility for truly becoming someone who did not commit those acts.

Regarding this issue, the historical process of identification or deidentification relates to present historical narratives: the "we", this collective historical identity, actually depends on present narratives building this sense of collectivity. As mentioned earlier, we do not all identify with the same singular historical experience or with the same universal agent. In the case of the Holocaust, the collective identity of the perpetrators is intertwined with German national identity, while the victims identify with what it means to be Jewish. If we ask about who is this "we" who ought to be responsible for the historical deed, we might come up with different answers regarding the narrative which in the present identifies certain community as that "we". It is important to keep in mind that diverse aesthetic manifestations might talk to the spectator differently, depending on their own process of historical identification with a particular "we". Moreover, responsibility is attributed according to the spectator's own historical and collective narrative about who he is.

Despite this attribution of specific responsibilities, it is true that there is an undeniable sense of humanity which turns such horrifying events into something that appeals to us on a personal level. Auschwitz is a sublime historical event because it causes in us, taking Burke's famous words, "astonishment [...] in which all its motions are suspended, with some degree of horror" (2010, p. 73). Furthermore, in Runia's (2014)

2 This notion has also been studied by Martin Jay, under the light of Ankersmit's theory and trauma or by John Sanbonmatsu. However, I believe that an analysis that brings forward both the notion of aesthetic experience and commemoration is key and lacking in these articles. 
wordsthis sublime condition is the result of a decision to do something under "the urge" (p. 337) of a "Why not?" (p. 39) -it is, what he calls, a cultural vertigo:

Vertigo thus is the condition in which we may jump into the unknown, in which we may start to do things that are at odds with what we regard as our identity, in which we put a way of life on the line (Runia, 2014, p. 336).

The problem is that we might discover, after we have taken that jump into the unknown that where it led us and who we were, were indeed monsters. The next question is then: how can we forgive ourselves without forgetting?

\section{The aestheticized experience of reconciled commemoration}

I hold that an aesthetic experience of what is unsayable is a form of commemoration which can help us become what we are no longer because it brings forward, into this very present, the presence of the past Runia discusses in Moved by the Past -which Ankersmit has defined as "sublime historical experience" (2005, p. 265). The capacity of aesthetic experience to achieve true reconciliation with our former despicable identities depends on this point. Furthermore, when commemorating a historical catastrophe, we separate ourselves from it -yet, in this act of commemoration we need, in the first place, to remember that what we did was indeed imaginable and, second, we need to overcome the historical link that ties us to those former identities we wish to forget. It is fundamental that we do not lose sight of the fact that becoming who we are no longer ought not to be a historical narrative of a posteriori identity dissociation like in Bem's self-perception theory, but a normative claim that addresses the future in relation to the present. It is an act of understanding that who we are is defined by discontinuity and that we might not have fathomed who we were until we look at the deeds we committed -what it ought not be is a reconstruction of former identities that denies events by turning them into something "unimaginable" (Ankersmit, 2005, pp. 343-344). ${ }^{3}$

This aforementioned cultural vertigo takes many names in Runia's work: it is the capacity of surprising ourselves, it is inventio, the very same "why not?", the metamorphosis -all of them are different terms Runia gives to the agent's ability to commit sublime acts. ${ }^{4}$ These terms simply refer in different ways to the historical

3 This nuance I have made about the historical narration of our former identities could be understood under the light of what Ankersmit calls "the association of dissociation" when talking about the sublime historical experience.

4 This becomes very clear on chapter 3 where Runia claims that "Inventions are the proactive words and deeds-as I have called them in the introduction—with which we surprise ourselves" (p. 185); again, later on, in chapter 6: "it is, of course, a rather disquieting thought: the principle that in the beginning was the deed implies that we engage upon war and revolution because every now and then we are tempted to flee forward into a sublime "Why not?" (p. 319); and, finally, on the very same chapter: "In rhetoric inventio has less to do with creation ex nihilo than with something quite different but no less radical: metamorphosis" (p. 341). 
discontinuity of the reasons and motives that lead agents to act, thus, to perform deeds that the grand narratives of coherence interpret a posteriori. Runia argues that these discontinuities are the ones that transform our historical identities and shape who we are in the present. Sublime historical events help us realize who we actually were before they happened, so that which we thought was unimaginable could indeed have taken place. Hence, when we become what we are no longer, we realize that in fact these unimaginable events were imaginable - what we have become is someone that can imagine. The gain of historically conceptualizing events as sublime, resides in the fact that it helps us realize who we actually were before the deed. This is what Runia (2014) means with his tenth thesis in Moved by the past: "By burying the dead we create not our future, but our past" (p. 57). We can only understand who we were once we have buried our former identities, because we can only know ourselves after we have committed the deed -hence, Runia's (2014) emphasis on Goethe's famous words: "In the beginning was the deed" (p. 286).

Here is where I have to take over the question proposed at the end of the previous subchapter: what happens when we realize we were monsters? How can we continue to live with our former identities? I believe the key for a possible reconciliation with previous historical identities lies in the notion of commemoration Runia (2014) proposes: "This desire to commemorate is, in my opinion, the prime historical phenomenon of our time" (p. 26). It is in this desire for commemoration that the past appears in our present and reveals something not only about this aforementioned past but about our present and our future. Runia's second thesis is that "Commemoration is trying to answer the question 'Who are we that this could have happened?"' (Runia, 2014, p. 32). Hence, it is a quest for knowing not only who we were but also who we actually are. This act of commemorating is the one that has to lead the way to "transform ourselves in people who did not do it" (p. 42) who did not commit those "sublime acts of people". Furthermore, Runia understands commemoration as "the necessary concomitant of the exquisitely human faculty of externalization" (p. 55) -what this means is that commemorating is an act of externalization that guarantees closure and perpetuation at the same time. By commemorating we reconcile with those sublime historical events that had been detached from ourselves: we are not the ones who committed them, even if we were before. In this case, the act of externalization manifests in the field of the visible, thanks to the emergence of four photographs nobody thought they existed.

At this point I have to come back to where I started: the four Sonderkommando images are an exemplary form of commemoration because they make visible an unimaginable event and force a new distribution of the sensible thanks to the politics intrinsic in aesthetic depictions. Moreover, they make present the events depicted in them by means of their presence. This presence is what, according to Runia (2014), we look for when we commemorate -it is the desire of being in touch with the reality of things that have already fled. Presence is then highly related to the account of 
continuity and discontinuity in the same terms our identity is related with who we are in the present and who we were in the past. For Runia (2014), "the concept of metonymy is a surprisingly suitable tool for coming to grips with discontinuity and with the need for presence" (p. 143). Metonymy is "presence in absence" which is precisely what the four images of Auschwitz are showing us: they are "Not a veil-image of the fetish, but the tear-image from which a fragment of the real escapes" (Didi-Huberman, 2008, pp. 80-81). This tearing experience is what takes place in metonymy, where we become aware of the fragmentary truth we perceive in the image. Despite being mere blurry fragments, the four images are still a piece of history - precisely the kind of history historians have neglected in favor of the continuity of grand narratives. They contain a small piece of truth from a whole complex reality and that is why they are paradigmatic examples of metonymy. The power of these images resides in their ability to enable commemoration through this fragmentary narration -thus, metonymy - which is nonetheless political in its very nature:

At the same time, these figures redistribute the relation between the single and the multiple, small numbers and large numbers. That is how they are political, if politics in the first instance consist in the changing of place and the counting of bodies. In this sense, the political figure par excellence is metonymy, which gives the effect for the cause or the part for the whole (Rancière, 2009, p. 97).

An aesthetic experience of the four images from Auschwitz can help their spectator reconcile with their past if they let their presence invade their here and now, thus, if they let their present identity be affected by their past. These metonymies transfer the presence of a sublime historical event thanks to their own mémoire involotaire -as Benjamin (1989) put it: "not only do its images appear without being called up; rather, they are images we have never seen before we remember them. This is most clearly the case in those images in which - as in some dreams- we see ourselves" (p. 1064). The notion of metonymy Runia has in mind is the one that "transposes something to the present" and, at the same time, "contains what was left behind" (Runia, 2014, p. 183). Finally, I cannot think of a better way to describe the presence of the Sonderkommando photographs than Hansen's interpretation of the auratic experience we undergo when facing an image:

What is illuminated by the flash and thus photographically preserved in memory is neither the content of the message nor the child's room but an image of our "deeper self," separate from and outside our waking, everyday self, which "rests in another place and is touched by shock [Choc] as is the little heap of magnesium powder by the flame of the match." And, Benjamin concludes suggestively, "it is to this immolation [Opfer] of our deepest self in shock that our memory owes its most indelible images" (2008, p. 347). 


\section{Conclusion}

As a conclusion, I would like to recapitulate the steps which have guided my analysis and also clarify once more my final aim when considering these photographs as depictions of a sublime historical event. These four images from Auschwitz are relevant pieces of a historical truth which have been neglected because of their fragmentary and discontinuous character. However, it is when faced with these fragments of truth, these tear-images, that the viewer is also faced with their former identities, their sublime historical acts, and when they finally come to face their past, enabling a possibility for truly becoming someone they are no longer instead of accommodating their need of continuity with a grand historical narrative. The aesthetic experience of photographic metonymy might be the best possible way to achieve commemoration and reconciliation with collective former identities. Moreover, what can an aesthetic experience in the present add to the experience of the past? Regarding the politics of aesthetics, these types of images, exemplified through the Sonderkommando photographs, open a new distribution of the sensible which allows us to represent, visualize and speak about things that were unimaginable for our former selves. This possibility might also help us move forward by being "moved by the past" and forgiving our former selves. In this sense, images might help the viewer to take historical collective responsibility and to finally fathom who they were before their deeds took place.

\section{References}

Ankersmit, F. R. (2005). Sublime historical experience. Stanford University Press.

Barthes, R. \& Howard, R. (1982). Camera lucida: reflections on photography. Hill \& Wang,

Benjamin, W., Tiedemann, R. \& Schweppenha, H. (1989). Gesammelte Schriften, 7 vols. 7, 350-84. Suhrkamp Verlag.

Bratu Hansen, M. (2008). Benjamin's Aura. Critical inquiry, 34(2), 336-375. https://doi. org/10.1086/529060

Burke, E. (1792). A philosophical inquiry into the origin of our ideas of the sublime and beautiful. J. J. Tourneisen.

Didi-Huberman, G. (2008). Images in spite of all. Four photographs from Auschwitz. Chicago University Press. Images in spite of all. Four photographs from Auschwitz

Jay, M. (2018). Sublime historical experience, real presence and photography. Journal of the Philosophy of History, 12(3), 432-449. https://doi.org/10.1163/18722636-12341406

Rancière, J. (1999). Disagreement: politics and philosophy. University of Minnesota Press.

Rancière, J. \& Elliott, G. (2009). The emancipated spectator. Verso. 
Rancière, J. \& Rockhill, G. (2004). The politics of aesthetics: the distribution of the sensible. Continuum.

Robertson, F. (2010). The work of art in the age of its technological reproducibility, and other writings on media. Vol. 51. Johns Hopkins University Press. https://doi.org/10.1353/ tech.0.0415

Runia, E. (2014). Moved by the past: discontinuity and historical mutation. Columbia University Press. https://doi.org/10.7312/columbia/9780231168205.001.0001

Sanbonmatsu, J. (2009). The holocaust sublime: singularity, representation, and the violence of everyday life. American Journal of Economics and Sociology, 68(1), 101-126. https:// doi.org/10.1111/j.1536-7150.2008.00617.x 


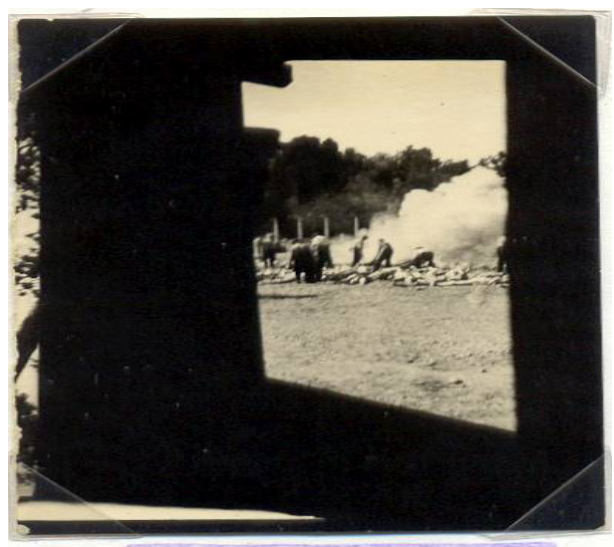

Image $\mathrm{n}^{0} 280$

The Sonderkommando photographs (1944) Source: Public domain

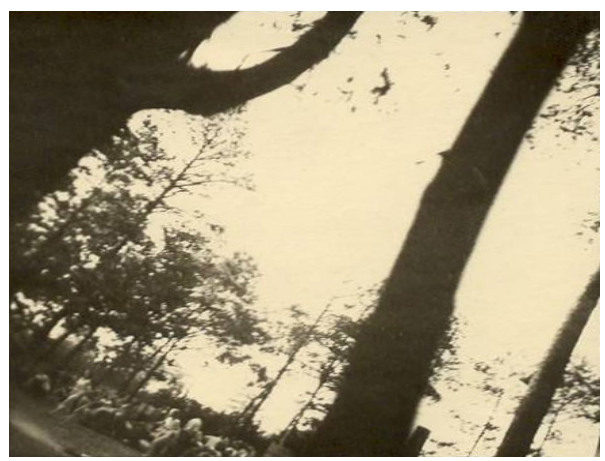

Image $\mathrm{n}^{0} \mathbf{2 8 2}$

The Sonderkommando photographs (1944)

Source: Public domain

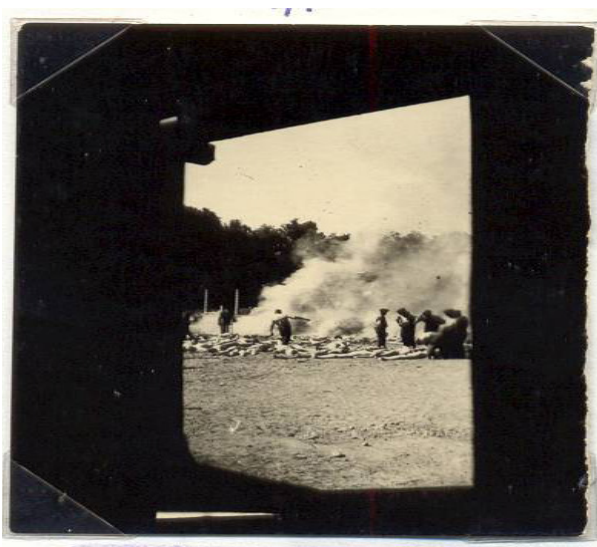

Image $n^{0} 281$

The Sonderkommando photographs (1944)

Source: Public domain

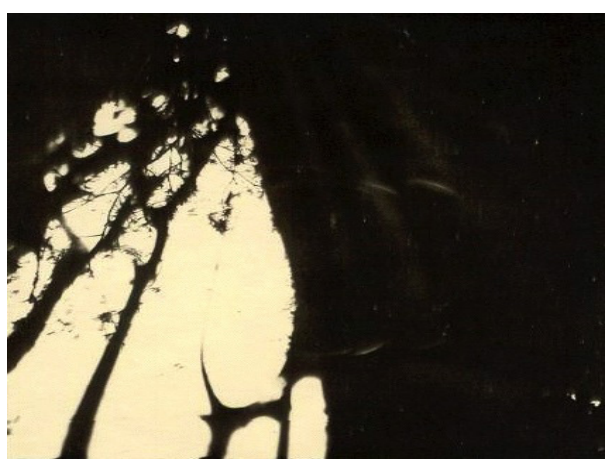

Image $\mathrm{n}^{0} 283$

The Sonderkommando photographs (1944)

Source: Public domain 